\title{
Gingival crevicular fluid - composition and clinical importance in gingivitis and periodontitis
}

\begin{abstract}
Among many substances used in clinical diagnosis, such as peripheral blood, gum homogenate, saliva and gingival pocket fluid, it is the latter that seems to bean extremely valuable diagnostic and research material. Identification of mediators in gingival crevicular fluid, both in the healthy gingival fissure, as well as in pathological periodontal pockets can be a valuable supplement to the initial diagnosis and describe the mechanism of gumorperiodontal diseases.

Changes in the concentration of individual components in the gingival crevicular fluid may be used to assess the severity of periodontal disease.

There are numerous methods for collecting fluid from the sulcus described: Micro-capillary drainage, micropipette drainage, rinsing pocket or drainage with the use of methylcellulose strips and then reading with Periotron.

Gingival fluid is composed mainly of blood electrolytes and organic molecules, i.e. albumins, globulins, lipoproteins or fibrinogen and cellular components as well as peptides, bacteria and enzymes.

Therefore gingival crevicular fluid (GCF) is treated as a window for noninvasive analysis of periodontitis, taking into account indicators and markers of connective tissue and bone destruction.
\end{abstract}

Keywords: gingival crevicular fluid, periodontitis, gingivitis.

DOI: $10.2478 /$ pjph-2014-0022

\section{INTRODUCTION}

Modern diagnostic methods changed the face of medicine. The doctor does not have to rely solely on what can be heard and seen or examined palpable, but one can also enjoy a variety of laboratory tests and imaging, to facilitate the diagnosis and differentiation of diseases. Biochemical studies require tissue or body fluid sample, where the biomarkers are evaluated. The most versatile material is blood. Depending on needs saliva, gingival crevicular fluid, cerebrospinal fluid, sweat or urine can be also used [1].

In the middle of the last century researchers attempted to examine the anatomy and physiology of the sulcus, which allowed to determine the composition and role of gingival fluid [1-3].

The need to find a non-invasive test method in periodontitis drew attention to the sulcus fluid that is produced in small quantities evenin a completely healthy periodontium, and its composition is close to that of blood plasma.

Gingival crevicular fluid is an exudate secreted by the gums that can be found in the crevices located at the point where the gum line meets the teeth. Concentrations of this fluid are usually low, but can spike when an inflammatory process occurs in the oral cavity. Patients with active gum disease tend to have more gingival crevicular fluid, and research on this body fluid suggests that testing during periods of active inflammation can provide important and useful information about the outbreak [1,2].

Gingival crevicular fluid (GCF) is treated as a window for noninvasive analysis of periodontitis, taking into account indicators and markers of connective tissue and bone destruction so it could be a useful indicator in determining the severity of gum disease [3].

The volume of fluid coming out of the pocket increases together with raising vascular wall permeability caused by the action of inflammatory mediators. Its composition changes during the development of inflammation [2,4]. According to researchers, GCF protein level obtained from the sulcus with clinical symptoms of inflammation is much higher and has a concentration similar to the concentration of proteins in blood serum. Thus, the fluid produced in the fissure with no clinical signs of gingival inflammation is a physiological infiltrative material $[1,4]$.

Gingival fluid is composed mainly of blood electrolytes and organic molecules, i.e. albumins, globulins, lipoproteins or fibrinogen and cellular components. In addition, the gingival fluid also contains of peptides, bacteria and enzymes (Table 1). The presence of immune cells is associated with active transport, while the rest of components, depending on the size of molecule, show a passive filtration [4].

2 'Dentartis' Dental Office, Lublin, Poland 
TABLE 1. Comparing the content of the individual cells of the immune system in gingival crevicular fluid and in peripheral blood [4].

\begin{tabular}{lcc}
\hline \hline \multicolumn{1}{c}{ Cell type } & GCF & Peripheral blood \\
\hline Neutrophils & $91-97 \%$ & $60 \%$ \\
\hline Monocytes / Macrophages & $2-3 \%$ & $5-10 \%$ \\
\hline Lymphocytes & $1-6 \%$ & $20-30 \%$ \\
\hline T lymphocytes & $29 \%$ & $50-75 \%$ \\
\hline B lymphocytes & $71 \%$ & $15-30 \%$ \\
\hline
\end{tabular}

Over half a century ago Sharry and Krasse proved that nearly $50 \%$ of cells collected from the gingival groove, even with clinically healthy surroundings, are leukocytes, while derived from other areas of the oral cavity - contained only $2 \%$ of leukocytes. Neutrophils (PMNs - polymorphonuclear leukocytes) constitute $91-97 \%$ of the immune system cells and quantitatively prevail among all leukocytes in gingival fluid [5]. The remaining (2-3\%) are monocytes/macrophages, T lymphocytes (29\%), B lymphocytes (71\%) (Table 2). The ratio of $\mathrm{T}$ cells to $\mathrm{B}$ is $1: 2,7$ which is different than in peripheral blood.

Gingival epithelium is constantly renewed in the sulcus - it takes from 4 to 6 days for connecting epithelium and 10 to 14 days for the fissure epithelium respectively. Therefore

TABLE 2. Inflammatory mediators present in the gingival crevicular fluid.

\begin{tabular}{|c|c|}
\hline \multicolumn{2}{|c|}{ The mediators of the immune response } \\
\hline \multicolumn{2}{|c|}{ Total and subgroups of immunoglobulin $\operatorname{IgG}$} \\
\hline \multicolumn{2}{|c|}{ The mediators of the inflammatory response } \\
\hline \multicolumn{2}{|c|}{ Arachidonic acid derivatives such as $\mathrm{PGE}_{2}$} \\
\hline \multicolumn{2}{|c|}{ Cytokines, such as IL-1, IL-2, IL-4, IL-6, TNF $\alpha$} \\
\hline \multicolumn{2}{|c|}{ Enzymes and enzyme inhibitors } \\
\hline Proteolytic enzymes & Hydrolytic enzymes \\
\hline Collagenase & Arylsulfatase \\
\hline Elastase & $\beta$-glucuronidase \\
\hline Cathepsin-B & Alkaline phosphatase \\
\hline Cathepsin-G & Acid phosphatase \\
\hline Cathepsin-D & Myeloperoxidase \\
\hline \multirow[t]{2}{*}{ Tryptase } & Lactoferrin \\
\hline & Lysozyme \\
\hline \multicolumn{2}{|c|}{ Bone-specific proteins } \\
\hline \multicolumn{2}{|c|}{ Osteonectin } \\
\hline \multicolumn{2}{|c|}{ Phosphoprotein (N-propeptide) } \\
\hline \multicolumn{2}{|c|}{ Osteocalcin } \\
\hline \multicolumn{2}{|c|}{ Telopeptide of type I collagen } \\
\hline \multicolumn{2}{|c|}{ Tissue breakdown products } \\
\hline Component & The product breakdown \\
\hline Fibronectin & Split components of fibronectin \\
\hline \multirow[t]{2}{*}{ Collagen } & Hydroxyproline \\
\hline & The final peptides \\
\hline Proteoglycans & Glycosaminoglycans \\
\hline \multirow[t]{3}{*}{ Glycosaminoglycans } & Heparin Sulfate \\
\hline & Chondroitin-4-sulphate \\
\hline & Chondroitin sulphate- 6 \\
\hline
\end{tabular}

the epithelial cells, which undergo exfoliation, are always present in the gingival fluid. Initial response of immunological system to inflammation is associated with activation of $\mathrm{T}$ lymphocytes (helper $\mathrm{T}$ lymphocytes and among them primarily Th2 but also Th1, Th0, cytotoxic T lymphocytes and regulatory $\mathrm{T}$ cells). In the region of the connecting epithelium specific mucosal lymphocytes $T \gamma \delta$ appear [4]. In GCF, in addition to T lymphocytes, a high level of lymphocytes B is observed. However, even in clinically healthy periodontium, small amounts of $\operatorname{IgG}$ and $\operatorname{IgA}$ antibodies can be found in GCF. IgG1 and IgG4 antibodies are listed as those whose level in the gingival crevicular fluid increases up to 25 - fold during the development of inflammation, compared with their concentration in serum $[3,4]$.

sIgA, secreted into gingival crevice, plays an important role in antimicrobial defense. Scientists have proven the existence of a lower level of IgA in gingival fluid taken from the area of periodontitis compared to the fluid collected from the area covered by the inflammation of the gums, which would suggest an individual profile of secretion of IgA antibodies that determine the progression of the inflammatory process $[2,4]$.

Changes in the concentration of individual components in the gingival crevicular fluid may be used to assess the severity of periodontal disease. In addition, not only previously mentioned antibodies, but also other cellular components are present in the GCF i.e. IL-1 $\beta$, antagonist of receptor IL-1, IL-2, IL-4, IL-6, IL-8, IL-10, TNF- $\alpha$ as well as the inflammatory mediators,i.e., Prostaglandin E2, thromboxane B2, and leukotriene B4. Attempts have also been made to examine neutrophil secretory activity, taking into account the levels of enzymes in GCF such as metalloproteinases, elastase, $\beta$-glucuronidase, myeloperoxidase, cathepsin B, D, $\mathrm{G}$ and as inhibitors of elastase and cathepsin [1-4]. There is a chair-side commercial test which allows to examine the concentrations of ALP (alkaline phosphatase) released togingival fluid by osteoblasts, neutrophilsand fibroblasts. In addition, there is a test $\left(\right.$ PerioGard $\left.^{\mathbb{B}}\right)$ which enables to confirm elevated levels of AST (aspartate aminotransferase) released during cell death. Raised AST and ALP amount in gingival fluid indicates an active process of periodontal destruction. Other degradation products of connective tissue collagene, such as chondroitin sulfate and hydroxyproline, are reported to be indicators of the advancement of periodontal disease - periodontitis [4].

Alkaline phosphatase is an enzyme of the mature, active osteoblasts. It is a recognized marker of bone formation, although it should be noted that it is not an enzyme specific for bone. Bone and liver phosphatase are products of the same gene, but they undergo different post-translational modifications [6].

Diagnostic tests based on the use of GCF sample can also indicate the presence of bacteria such as: Porphyromonas gingivalis, Actinobacillus actinomycetemcomitans and Prevotella intermedia. Perioscan Test ${ }^{\circledR}$ (Oral-B Laboratories) using BANA enzymatic reaction, allows to detect bacteria which contain peptidase trypsin, - Porphyromonas gingivalis, Treponema denticola, Tannarella forsythensisi Capnocytophaga spp. Real - Time PCR (PCR - polymerase chain reaction), enzyme-linked immunoassays - ELISA 
(Evalusite), and genetic engineering tests, using DNA probes specific for several periopathogens (Omnigene) can also be performed [4].

Material collected from the sulcus or periodontal pocket can be a very valuable and little invasive diagnostic material. There are numerous methods for collecting fluid from the sulcus described: Micro-capillary drainage, micropipette drainage, rinsing pocket or drainage with the use of methylcellulose strips (Periopaper strips - Oraflow Inc.) and then reading with Periotron (Oraflow Inc.).

Many authors observed a correlation between the level of sex hormones in serum and gingival fluid during different stages of a woman's life, such as puberty, the menstrual cycle and menopause. Rahnama (2009), examining the levels of cytokines in serum and saliva in women during menopause, observed more than 600 -fold increased levels of IL- $1 \alpha$ in saliva with respect to the concentrations of these cytokines in the serum $[6,7]$.

There are scientific reports that present the relationship between the concentrations of cytokines and proteins in blood serum and fluid sulcus. Mostly lower levels of serum proteins are noted in comparison with the levels of these substances in the gingival crevicular fluid. Comparing the levels of IL-1 $\beta$ and IL- 8 in the blood serum of gingival fluid, Fiorini et al. demonstrated that the level was 40 to 80 times higher in the GCF [8].

The biochemical analysis of the fluid offers a non invasive means of assessing the host response in periodontal disease. Active phase of periodontal disease process can be measured or assessed by the constituents of gingival fluid. Bacterial enzymes, bacterial degradation products, connective tissue degradation products, host mediated enzymes, inflammatory mediators, extracellular matrix proteins either together or individually can be detected in higher levels in gingival crevicular fluid during active phase of periodontitis.
I declare that there is no conflict of interests which could have influenced impartiality and reliability of the paper entitled "Gingival crevicular fluid - composition and clinical importance in gingivitis and periodontitis".

\section{REFERENCES}

1. Ganowicz E. Salivary Diagnostics - Diseases of the Oral Cavity. Dent Med Probl. 2011;48(3):421-30.

2. Miller CS, Foley JD, Bailey AL. et al. Current developments in salivary diagnostics. Biomark Med. 2010;4:171-89.

3. Bostanci N, İlgenli T, Emingil G, et al. Gingival crevicular fluid levels of RANKL and OPG in periodontal diseases: implications of their relative ratio. J Clin Periodontol. 2007;34:370-6.

4. Gilowski Ł, Wiench R, Płocica I, et al. Płyn dziąsłowy - czym jest i co umożliwia? Czas Stomatol. 2007;3:171-8.

5. Sharry JJ, Krasse B. Observations on the origin of salivary leukocytes. Acta Odontol Scand. 1960;18:347-58.

6. Rahnama M, Świątkowski W, Zaręba S. An assessment of the alkaline and acid phosphatase activity in rats serum during experimental postmenopausal osteoporosis. Rocz Państ Zakł Hig. 2002;53(3):283-91.

7. Rahnama M. Osteoporoza pomenopauzalna w badaniach doświadczalnych i klinicznych. Ocena wpływu poziomu wybranych markerów obrotu kostnego, ekspresji ich genów oraz szlaku RANKL/RANK/OPG na gęstość tkanki kostnej. Lublin: Uniwersytet Medyczny w Lublinie; 2009. p. 322.

8. Fiorini T, Vianna P, Weidlich P, et al. Relationship between cytokine levels in serum and gingival crevicular fluid (GCF) in pregnant women. Cytokine. 2012; 58(1):34-9.

\section{Corresponding author}

Łukasz Czupkałło

Chair and Department of Oral Surgery

Medical University of Lublin

Karmelicka 7 st., 20-081 Lublin, Poland

tel. +48 (81) 528-79-50

E-mail: czupkallo@gmail.com 